全傳熱面謮 (火の側) $238 "$

傳熟面锖と火格子面皘の比 $53: 1$

(b) 岸水車

\section{軸數 4}

車軸通徑 $1030 \mathrm{~mm}$

固定軸距（挠部の二軸） $1400 "$

ボギー軸距

$1800 "$
機關車の蓮轉整備に於け万重量 $109300 \mathrm{~kg}(113600 \mathrm{~kg})$

全軸距 4750 "

注意括孤內の值は複式機關車に對する分てあろ。

斯樣に殆ど同一博力を有すへき單複二倳の形式の機閏車を作つた理由は複式の得

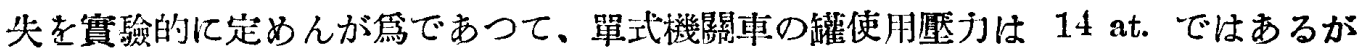
16 at. までに耐ゆる樣復式機關事つ鑵さ同一の構造に作られてある。

尖等機關車の製作に就ては各部に充分なる互換性を倠せしむるため Alna（Allgemeinen Iokomotiv-Normen-Ausschuss) より分歧した Elna (Engere Lokomo-

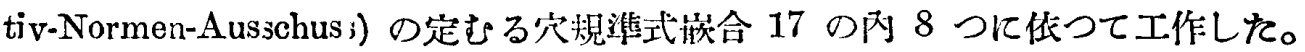

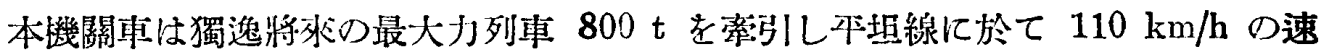
度を以て走行するに適合するものであるが、從來の機關車に比し特異の點は傅熱面 積に對する火格子面積が割合に大きんことと㸝動裝犆が異ることである。即ち從來

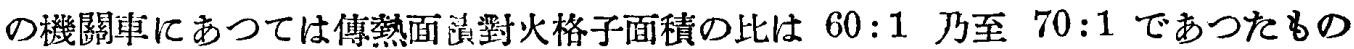
が、然燒率を減少するため本機關車に於ては 53:1 になつて居る。又制輪子は從 來制動輪の車軸中心線上に無いものが多かつたが、制動の際の軸重變化を避けるた め悉く車軸中心線上に犆き、動輪に在つては制動壓うを軸重の $170 \%$ に、ボギー 耣に在つては $65 \%$ に採つてあるがての割合の大なるてと亦亦聳來の例と異るとて ろである。何本文には本機關車構造の詳細に沙つて数多の圆と共に說明が扣へられ てある。

\section{2. 船舶およど舶用㙨關}

【1.19】螺旋軸の鹰玲及び折損 [The Mar. Engr. \& Motorship Builder,

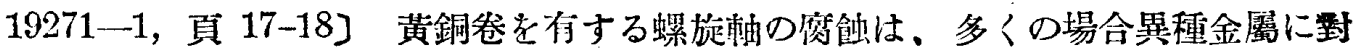
する海水の流電作用に因り發生し、黃銅卷端の直前又は直後のものが最も危險であ ると考へられて居る。此の種の腐刢は一般に表面的なれ其、有效徑を小にして强力 
を減方る。然し一般に螺旋軸の腐蝕は、黃錩然端に近接し圆周的に軸身に喰ひ入る もの多く、僅々二三年閻使用の物に發見するてとも少くない。之に依て考ふるに螺 旋軸の損傷は海水に依る腐蝕以外の影響も有ることが明かである。ボス，軸及び黃 銅卷を一體之考へると、軸身裸出部は銳い溝と見做され、大なる內力を受けること となるが、經驗上からも最危險部で、キーの前端部や黃銅卷の後端部附近によく裂 疪を發生する。此の裂疵は、推進器の慣性力に依り又特に汽機空轉の際非常に增大

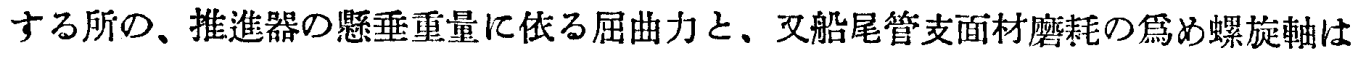

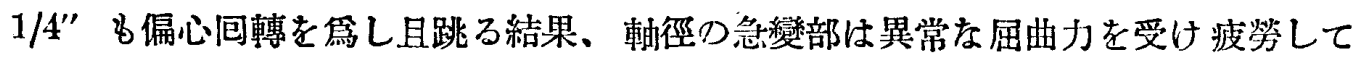
小表面疵を生じ次第に連䊧して逐に全周に亘る裂疵となり，之に海水が浸大して更 に狀態を惡化するものと考へられる。㧖力に因る裂疪は軸に科に、届曲に因るもの は直角に發生する。著者の知ろ螺旋軸の裂㖢は大部分屈曲力に因るもので、Cedor-

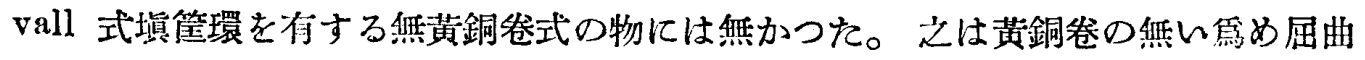

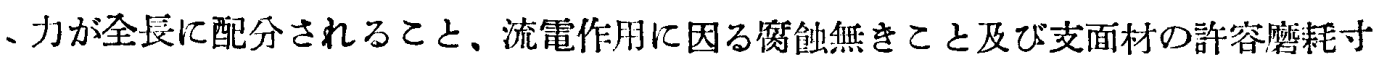
度が小なる故である。何洼著者は螺旋軸の最弱部は勾配起點部であるから、全通黃 銅癹軸の徑を分離黃銅卷式に比し $5 \%$ の輕減を竍して居るのが不思掌ですると述へ て居るが、譯者は直ちに之に同意するるのでは無いが一見解として記して置く。

$(\mathrm{KI})$

\section{5. 壓縮機、冷却機、送風機}

【120】水銀互斯壓縮機 [De Remer, Mech. Engng., Mid-Nov. 1926, 頁 1229-1233，圖 10了家庭用又は小規模工業用冷凍機として普通使用せらるる瓦斯 埾縮機に件ふ諸種の缺點、例へば瓦斯つ漏洩、注油の困難、吐出辫に件ふ困難、內部 謵機構の摩損に件ふ效率減退、水冷却式に於ける水不足の際の埾力過大防止困難等 を有せざる新式の壓縮機に關する記述でする。此新式擪縮機は最近十年間に發澾せ るものである。管を螺旋狀に卷き、水平と傾斜せる軸のまかりに、下端が一备轉中 の一部分丈け液中に浸る樣趣轉せしむれば、液體は管を通りて上端より排出せられ る。これは Archimedean Helical Pump である。此場合液つみならす液と液との 到に閉ぢ达められた空氣も又排出せられる。若し此管の上端に溜めを置く時は、空 氣之液之共に溜めの山に排出せられるが、此液のみを槽外に出す裝置をすれば、槽 